\title{
A OBRA DE MILTON HATOUM DOIS IRMÃOS E A ADAPTAÇÃO DA HQ DE FÁBIO MOON E GABRIEL BÁ COMO PROPOSTA DE LETRAMENTO LITERÁRIO E AMPLIAÇÃO DE REPERTÓRIO DOS ALUNOS DO $8^{\circ}$ ANO DO ENSINO FUNDAMENTAL II
}

\author{
Noemia de Azevedo Nascimento \\ Orientadora: Prof ${ }^{a}$ Dra. Patrícia Pedrosa \\ Botelho
}




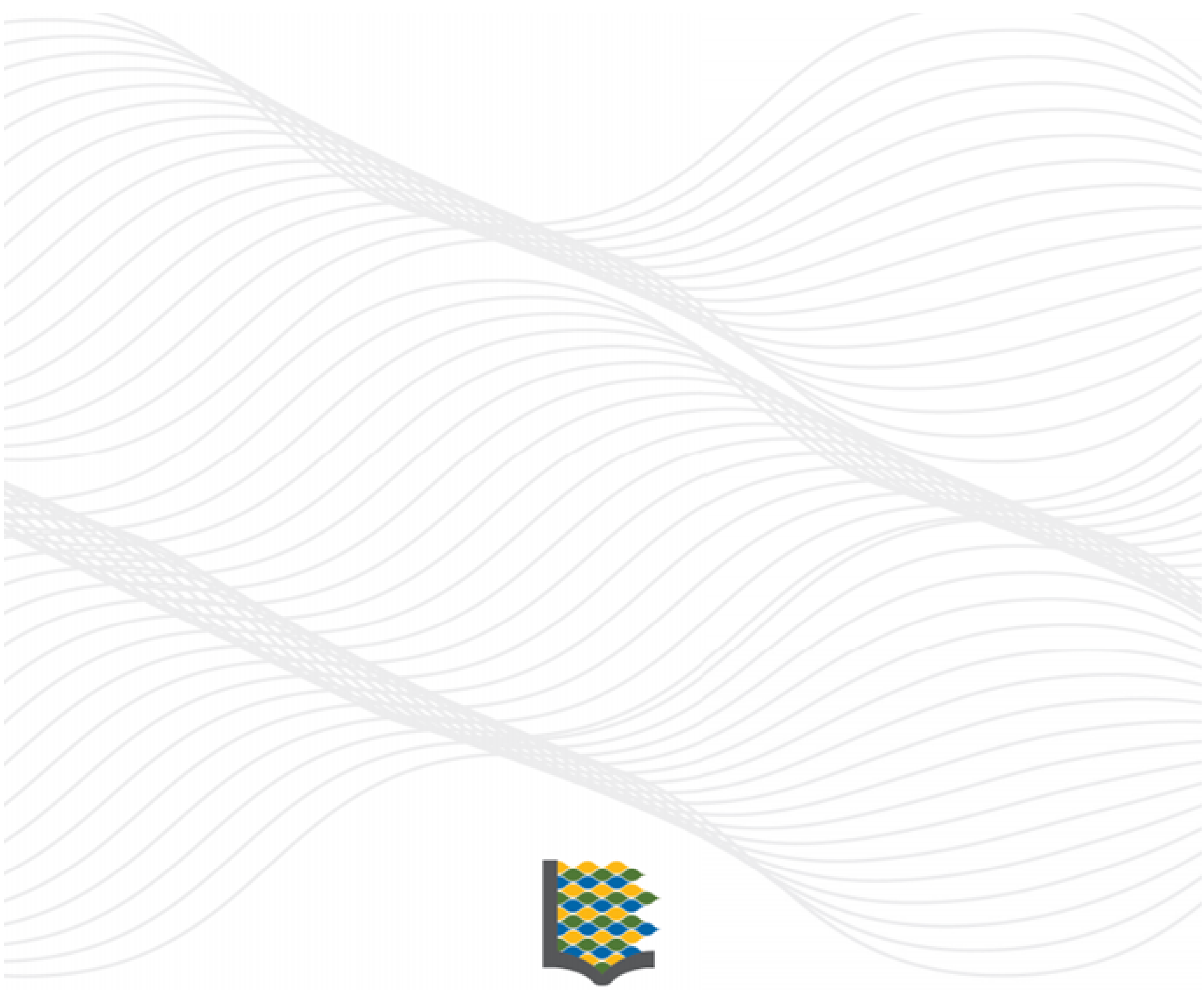


Ficha catalográfica elaborada através do programa de geração automática da Biblioteca Universitária da UFJF, com os dados fornecidos pelo(a) autor(a)

Nascimento, Noemia de Azevedo.

A obra de Milton Hatoum Dois irmãos e a adaptação da HQ de Fábio Moon e Gabriel Bá como proposta de letramento literário e ampliação de repertório dos alunos do $8^{\circ}$ ano do Ensino

Fundamental II / Noemia de Azevedo Nascimento. -- 2021.

$45 \mathrm{f}$. : il.

Orientadora: Patrícia Pedrosa Botelho

Dissertação (mestrado profissional) - Universidade Federal de Juiz de Fora, Faculdade de Letras. Programa de Pós-Graduação em Letras, 2021.

1. Repertório literário. 2. Competência leitora. 3. Retextualização. 4. HQ. 5. Milton Hatoum. I. Botelho, Patrícia Pedrosa, orient. II. Título. 


\title{
Ficha técnica
}

\author{
Organizadores
}

Elza de Sá Nogueira

Érika Kelmer Mathias

Luciana Teixeira

Marco Aurélio de Sousa Mendes

Natália Sathler Sigiliano

Patrícia Pedrosa Botelho

Thais Fernandes Sampaio 
Universidade Federal de Juiz de Fora

Mestrado Profissional em Letras

2021 


\section{Apresentação da Coleção de Cadernos Pedagógicos}

\section{PROFLETRAS/UFJF 2021}

Érika Kelmer Mathias

Natália Sathler Sigiliano

O mestrado profissional em Letras da Universidade Federal de Juiz de Fora tem assumido, desde a sua constituição, em 2013, o compromisso de um trabalho desenvolvido em prol da capacitação de professores de Língua Portuguesa da rede básica de ensino fundamental, o que tem contribuído para a melhoria da qualidade de ensino da região e do país.

Como uma maneira de formar professores em seu próprio campo de atuação, assim como de impactar professores fora do programa - a quem seja possível o acesso ao conhecimento das práticas de pesquisas realizadas -, a elaboração de produtos educacionais de ensino é inserida como requisito básico da formação dos professores que ingressam nesse mestrado. Desde 2013, esse trabalho esteve integrado à realização de uma prática pedagógica interventiva inserida no contexto de sala de aula em que o professor, agora também pesquisador, atuava.

No ano de 2020, um cenário educacional atípico se revelou em todo o Brasil - e no mundo - devido à pandemia provocada pelo novo coronavírus. Nesse ano, diversos alunos da Turma 6 do PROFLETRAS da UFJF já haviam iniciado, em fevereiro de 2020, a aplicação de suas propostas de intervenção em salas de aula presenciais, e outros tinham planos de fazê-lo ainda nos primeiros meses do mesmo ano. No entanto, como forma de assegurar a saúde dos diversos atores envolvidos na esfera escolar, as aulas presenciais precisaram ser subitamente interrompidas, no país, ao longo do mês de março de 2020. Diante dessa realidade, enquanto as redes privadas puderam 
rapidamente adotar ações no sentido de implementar um ensino remoto emergencial, adquirindo dispositivos, softwares e programas específicos, as redes públicas só conseguiram iniciar as atividades remotas meses depois do início da suspensão das aulas presenciais. Em alguns estados e municípios, 0 ensino remoto emergencial só se iniciou no segundo semestre de 2020 . Nesse sentido, o impacto nas pesquisas em curso no programa foi muito forte, não somente em função do intervalo de contato entre o professor-pesquisador e sua turma de atuação, como, principalmente, diante do novo cenário com o ensino remoto, cujas ações foram aplicadas de formas diferentes por estados e municípios: aulas remotas síncronas através de plataformas e/ou aplicativos de mensagens; aulas remotas assíncronas através de plataformas, TVs, material impresso e entregue aos alunos; materiais didáticos organizados pelas redes de ensino, sem a participação do professor; materiais criados e/ou adaptados pelos professores em seus anos e turmas de atuação; além de outras modalidades.

Dessa maneira, sensível a esse contexto, a coordenação nacional do mestrado profissional em Letras, por meio da resolução $n^{\circ}$ 003/2020, em 02 de junho de 2020, autorizou, de forma inédita, a possibilidade de serem realizadas, no âmbito do programa, propostas de ensino que não necessariamente tivessem caráter interventivo.

Diante disso, a Turma 6 do PROFLETRAS da UFJF colocou-se o desafio de realizar - ou de continuar a realizar - pesquisas as quais, mesmo em um contexto de muita apreensão e angústia quanto à vida e ao trabalho, resultaram em um conjunto de Cadernos Pedagógicos que apresentam características diversificadas quanto à situação de elaboração: alguns deles foram aplicados, mesmo em meio a um cenário atípico de aulas remotas; outros se compuseram de propostas de ações e atividades cujas aplicações poderão ser desenvolvidas futuramente.

É importante destacar também que, assim como todo texto que se constrói em interação com seus leitores, a constituição desses produtos pedagógicos contou - e contará - com uma rede de colaboração de diversos atores: professores e orientadores do programa, professores-discentes do 
mestrado profissional, professores participantes de bancas de qualificação e defesa, professores-colegas dos discentes do programa, alunos da rede básica que se propuseram a fazer parte das pesquisas e, ainda, professores que poderão conhecer, analisar, modificar e empregar estratégias inspiradas, em alguma medida, por aquelas aqui apresentadas por meio desta coleção.

Todos os Cadernos Pedagógicos tiveram como escopo a ideia de que "a especificidade da formação pedagógica, tanto a inicial como a contínua, não é refletir sobre o que se vai fazer, nem sobre o que se deve fazer, mas sobre o que se faz" (HOUSSAYE, 1995, p.28), no desejo de que esse pensamento guie não somente os autores, mas também os futuros leitores desses Cadernos a reflexões e ações sobre seus próprios fazeres pedagógicos.

É nessa esteira que, mais uma vez, apesar de todos os percalços do momento atual na educação, os Cadernos Pedagógicos produzidos no âmbito do PROFLETRAS/UFJF trazem propostas autorais e inovadoras de ensino de Língua Portuguesa e Literatura, revelando forte compromisso por parte dos professores envolvidos em sua produção com o ensino público de qualidade. 


\section{Apresentação do projeto}

Querido Professor,

Este caderno pedagógico foi criado com o objetivo de trazer a obra literária de Milton Hatoum, Dois irmãos, como fonte de estudo e reflexão para as aulas de língua portuguesa dos alunos dos anos finais do Ensino Fundamental II. Ele foi pensado com o intuito de ampliar o repertório literário e a competência leitora dos alunos.

Baseadas na sequência básica de Rildo Cosson (2018), várias atividades com perguntas orais e escritas foram feitas para que houvesse um aprofundamento da obra. O capítulo sete da obra foi utilizado através da adaptação para um seriado exibido pela Globoplay, além da adaptação em HQ de Fábio Moon e Gabriel Bá, para que os alunos pudessem retextualizar o final do enredo da narrativa. A intertextualidade com obras canônicas também foi contemplada em forma de exercícios, revelando que a literatura contemporânea mantém o olhar no passado para tentar fazer diferença no presente e, consequentemente, no futuro dos alunos.

Esperamos que esse material seja de alguma ajuda em sala de aula na sugestão de trabalho com a literatura, que você se aproprie dos conteúdos, adapte-os, se necessário, à sua sala e compartilhe-os.

Um abraço,

Noemia de Azevedo Nascimento

Clique aqui para baixar a dissertação. 


\section{Sumário}

Planejamento das aulas

1. Primeiro momento: Motivação

$\rightarrow$ Epígrafe de Carlos Drummond de Andrade

$\rightarrow$ Notícias de jornal sobre rixas familiares

2. Segundo momento: Introdução

$\rightarrow$ Apresentação do autor e da obra (Pré-leitura) 16

$\rightarrow$ Obra de Milton Hatoum 16

$\rightarrow$ Obra de Fábio Moon e Gabriel Bá $\quad 17$

$\rightarrow$ Biografia de Milton Hatoum 18

$\rightarrow$ Biografia de Fábio Moon e Gabriel Bá $\quad 19$

3. Terceiro momento: Leitura 20

$\rightarrow$ Leitura do livro de Milton Hatoum $\quad 20$

$\rightarrow$ Roteiro de leitura- capítulo 2

$\rightarrow$ Leitura da $\mathrm{HQ} \quad 26$

$\rightarrow$ Capítulo 07 da minissérie $\quad 30$

$\rightarrow$ Exercícios de intertextualidade 31

4. Quarto momento: Interpretação 36

$\rightarrow$ Retextualização com a HQ - Epílogo (Fábio Moon e Gabriel Bá) 37

$\rightarrow$ Final do capítulo de Milton Hatoum $\quad 42$

5. Referências bibliográficas 44 


\section{PLANEJAMENTO DAS AULAS}

Obra literária: Dois irmãos - Milton Hatoum e adaptação em quadrinhos de Fábio Moon e Gabriel Bá.

$8^{\circ}$ ano: 2 aulas de Português por semana

Momento $1-\quad 03$ aulas de 50 minutos

Momento 2 - 03 aulas de 50 minutos

Momento $3-\quad 06$ aulas de 50 minutos

Momento 4 - 02 aulas de 50 minutos

Momento 5 - 02 aulas de 50 minutos

Momento 6 - 04 aulas de 50 minutos

Momento $7-\quad 04$ aulas de 50 minutos

Momento 8 - 02 aulas de 50 minutos

Momento 9 - 04 aulas de 50 minutos

Momento 10 - 04 aulas de 50 minutos

Momento 11 - 02 aulas de 50 minutos

Momento 12 - 02 aulas de 50 minutos

Momento 13 - 02 aulas de 50 minutos

Momento 14 - 04 aulas de 50 minutos

Total $=44$ aulas

Antes da intervenção, uma pesquisa inicial intitulada "Sobre leitura e leitores" seria aplicada para a turma (vide anexo B da dissertação, p.65). 


\section{PROPOSTA INTERVENTIVA}

As atividades neste trabalho seguiram a sequência básica de Rildo Cosson (2018, p.51), sendo propostos quatro passos para o letramento literário dos alunos envolvidos nesse processo de intervenção: motivação, introdução, leitura e interpretação. Com a leitura da obra Dois irmãos (2000), de Milton Hatoum, e do mesmo enredo, porém produzido em forma de quadrinhos, por Fábio Moon e Gabriel Bá, os alunos teriam a oportunidade de recriar seu próprio desfecho, sendo coparticipantes do texto.

\section{Primeiro momento: motivação}

Chama-se de motivação a preparação que acontece para o início da leitura do texto pelo aluno.

Aula 1 - 3 aulas de 50 minutos - Pré-leitura.

Preparação para a leitura do livro Dois irmãos de Milton Hatoum e dos quadrinhos de Fábio Moon e Gabriel Bá.

$\rightarrow$ Como atividade de pré-leitura, a professora leria a epígrafe de Carlos Drummond de Andrade que consta na obra Dois irmãos e, depois, mostraria no datashow notícias de jornal sobre rixas familiares.

$\rightarrow$ Vamos ouvir com atenção o que vem escrito por um poeta brasileiro, Carlos Drummond de Andrade, na abertura da obra de Milton Hatoum e tentar responder oralmente às perguntas que serão feitas.

"A casa foi vendida com todas as lembranças todos os móveis todos os pesadelos todos os pecados cometidos ou em vias de cometer a casa foi vendida com seu bater de portas com seu vento encanado sua vista do mundo seus imponderáveis (...)" (DRUMMOND apud HATOUM, 2000, p. 10). 
1. Você sabe o que é uma epígrafe?

2. Que casa será esta que foi vendida? Quem morava nela?

3. Que pesadelos ou pecados uma casa teria para esconder? De quem?

4. Qual a importância de uma porta em uma casa? É apenas um enfeite?

5. O que é um vento encanado? Será que as portas batiam nesta casa apenas por causa do vento? Por quais motivos as portas bateriam?

6. O que poderia significar vender a casa com tudo o que nela havia?

7. Pelo dicionário, a palavra imponderável pode significar:

"Que não se pode pesar; Que não tem peso apreciável;

Que não se pode avaliar; Indigno de ponderação".

O que significaria a palavra imponderável no contexto lido?

Dicionário online de Língua Portuguesa. Disponível em: https://dicionario.priberam.org/imponderavel/ Acesso em: 29 de agosto de 2020.

$\rightarrow$ Apresentação das notícias sobre rixas familiares.

Perguntas orais:

1. Vocês conhecem casos de familiares que brigaram por dinheiro, por namoradas, afeto ou qualquer outro motivo?

2. O que vocês pensam sobre isso?

3. Como será o relacionamento das pessoas dentro dessa casa?

4. Já acompanharam casos nos jornais? Vamos ler alguns:

\section{Irmãos ciganos são presos suspeitos de matar parentes devido à rixa de mais de 200 anos}

Homens são acusados de matar o genro de um deles. Em outro caso, dupla teria esquartejado um sobrinho e enviado a cabeça ao pai dele. Eles foram achados em condomínio de luxo de Goiânia.

Dois irmãos ciganos foram presos suspeitos de matar parentes devidos a uma rixa familiar que dura mais de 200 anos, segundo a Polícia Civil. Em um dos 
casos, conforme a investigação, eles esquartejaram um sobrinho e enviaram a cabeça ao pai da vítima.

Jonatan de Almeida Dantas, de 22 anos, e Pascoal Ribeiro Dantas, de 48, foram presos no dia 31 de outubro, em um condomínio de luxo da capital, onde moravam há seis meses.

Os presos não foram apresentados à imprensa. O G1 não conseguiu localizar a defesa dos suspeitos até a ultima atualização dessa reportagem.

Eles tinham mandado de prisão em aberto por matar o genro de Pascoal em 2018, na Bahia, devido a essa briga entre duas partes da família, mas o delegado não soube explicar qual o motivo da rixa.

De acordo com os investigadores, o que mais chamou a atenção é que eles também são suspeitos de sequestrar e matar de maneira brutal um sobrinho, em 2017.

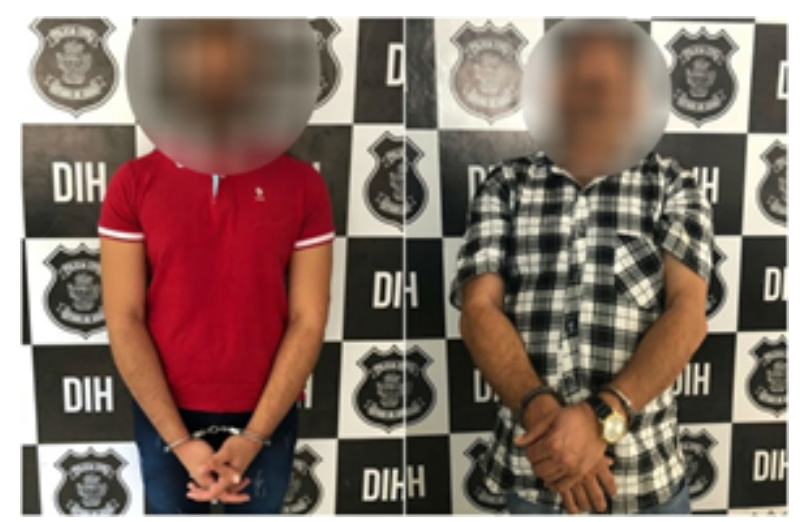

Irmãos ciganos Jonatan de Almeida Dantas, de 22 anos, e Pascoal Ribeiro Dantas, de 48, são presos em Goiânia suspeitos de matar parentes — Foto: Divulgação/Polícia Civil

"Os dois irmãos e outros dois homens sequestram um membro da outra parte da família e exigiram uma recompensa de $R \$ 5$ milhões. Como só foi pago $R \$$ 500 mil, eles mataram o sobrinho, esquartejaram e mandaram a cabeça para o pai da vítima", disse o delegado Rilmo Braga.

O pai da vítima, então, teria contratado um pistoleiro para matar todos os integrantes da parte rival da família. "Nessa disputa entre os dois lados, foram cometidos dez homicídios e 15 tentativas de homicídio", completou o delegado.

SANTANA, Vitor. Irmãos ciganos são presos suspeitos de matar parentes devido à rixa de mais de 200 anos. Disponível em: https://g1.globo.com/go/goias/noticia/2019/11/04. Acesso em: 04 de dezembro de 2019. Adaptado.

$\rightarrow$ Ainda de forma oral, os alunos responderão sobre o texto:

1. De onde saiu essa reportagem? Você tem o hábito de ler notícias de jornal?

2. Onde foram encontrados os assassinos? 
3. Como a vítima foi morta?

4. Por que aconteceu isso? Qual foi o motivo?

5. Existem outras opções para se resolver um conflito entre familiares envolvidos em uma disputa?

$\rightarrow$ Vamos ver outra notícia:

\section{Caso Von Richthofen}

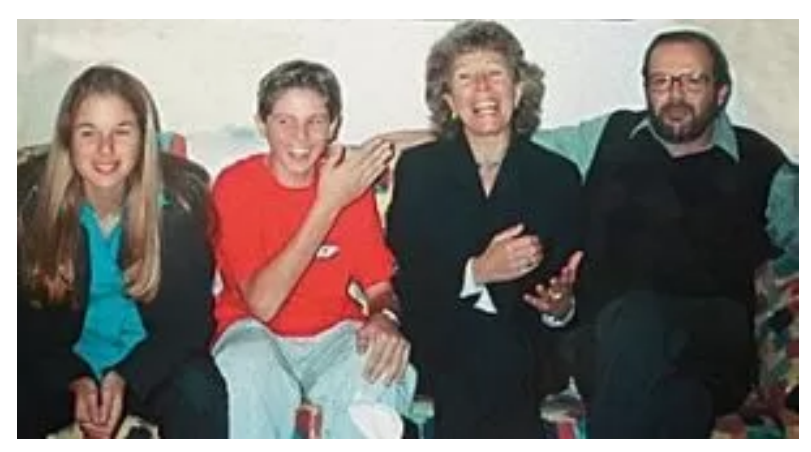

\section{O CASO}

Os corpos do casal jaziam na cama. Ambos com severas lesões na cabeça. Havia respingos de sangue no chão, na cama e na parede. No interior da boca da mulher havia sido enfiada uma toalha. Apenas o quarto e mais um cômodo da mansão estavam revirados, e, no chão, ao lado do corpo do homem, havia uma arma com somente um cartucho deflagrado.

Em outubro de 2002, no bairro do Campo belo, zona sul de São Paulo, na noite do dia 31, ocorreu um fato criminoso que, sem sombra de dúvidas, abalou o país. Era o início do "Caso Richtofen".

Manfred e Marísia von Richthofen, foram atingidos com diversos golpes na cabeça por dois agressores (Daniel e Cristian Cravinhos), que ficaram conhecidos como "os irmãos Cravinhos". O mórbido cenário guardava como pano de fundo um detalhe que chocaria a população brasileira, qual seja: o crime tinha sido planejado e comandado pela filha do casal, a bela Suzana von Richthofen, que na época dos fatos tinha apenas 18 anos de idade.

O homicídio fora movido pela seguinte razão: a família von Richthofen não aprovava o relacionamento amoroso entre Suzana (rica e culta) e Daniel (mais humilde e menos culto). A solução adotada pelo casal foi pragmática, ceifar a vida dos pais de Suzane.

Após a execução do plano, os criminosos resolveram simular um latrocínio, pois, dessa forma, sem a presença dos pais, Suzane poderia viver com seu namorado e, além disso, ganharia parte da valiosa herança deixada pelos seus pais. Para isso, contaram com a ajuda do irmão de Daniel, Cristian Cravinhos. 


\section{O JULGAMENTO}

$[\ldots]$

Após a votação na sala secreta, os jurados consideraram os três réus culpados da prática do duplo homicídio qualificado, tendo sido Daniel condenado à pena de 39 anos e 6 meses de reclusão, Suzane à pena de 39 anos de reclusão e Cristian 38 anos de reclusão.

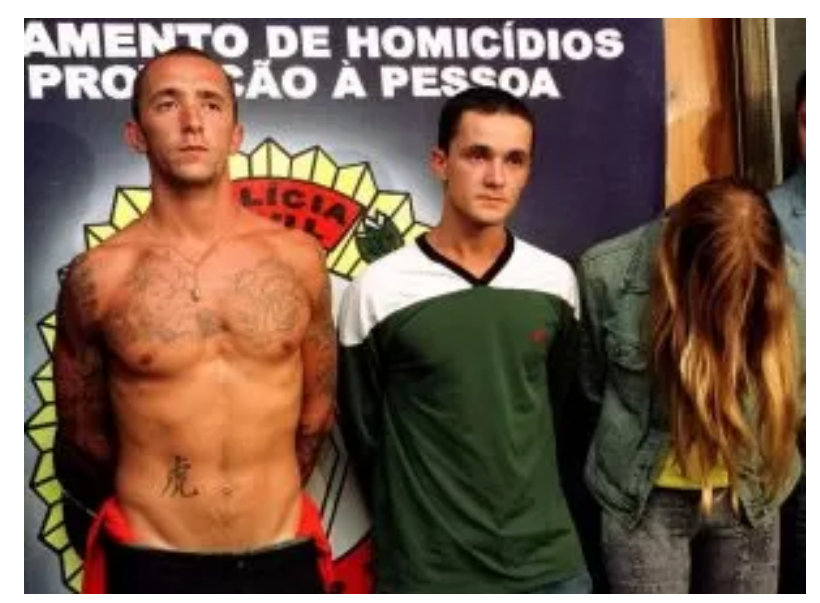

LIMA, Cezar de. Caso Richthofen. Disponível em: https://canalcienciascriminais.com.br/caso-richthofen/ Acesso em: 04 de janeiro de 2020. Adaptado.

$\rightarrow$ Ainda oralmente:

1. De onde saiu essa reportagem? Você conhece esse canal de comunicação?

2. Quem cometeu o crime nesse caso?

3. Quem planejou?

4. Por qual motivo esse crime foi planejado?

5. O que você pensa sobre o fato noticiado? Era a única forma de se conseguir o que queria?

6. Como poderíamos imaginar a relação entre os componentes desta família?

7. Você considera justa a condenação por 39 anos de reclusão? Por quê?

8. Esses são casos que ganharam grandes proporções, saindo nas mídias sociais. Mas ainda hoje acontecem casos difíceis entre familiares. Você conhece alguma obra literária que trate desse assunto? 
9. Podemos fazer alguma ligação entre as notícias lidas e a epígrafe de Drummond?

\section{Segundo momento: Introdução}

Aula 2 - 3 aulas de 50 minutos. Apresentação do autor e da obra (Pré-leitura).

$\rightarrow$ Ainda com o datashow, mostrar imagens da capa do livro Dois irmãos, de Milton Hatoum e da história em quadrinhos, fazendo questionamentos orais:

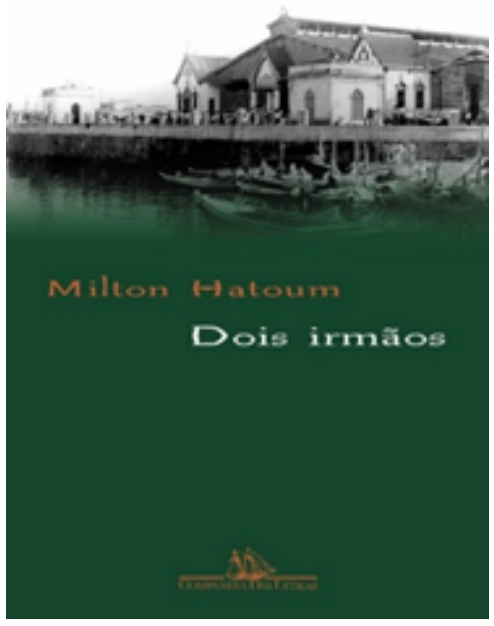

HATOUM, Milton. Dois irmãos. São Paulo: Companhia das Letras, 2000.

1. Que elementos visualizamos na capa?

2. Essa imagem nos diz que tipo de história o livro conta? Qual seria?

3. a) Pelo título, podemos dizer do que se trata a obra do autor? (Registrar no caderno de leitura).

b) Você imagina onde é o lugar desenhado na capa do livro? Por que você chegou a essa conclusão? 
$\rightarrow$ Nesse momento, a professora apresentaria a obra de Fábio Moon e Gabriel Bá, já que também seria utilizada na proposta interventiva.De forma oral os alunos responderiam:

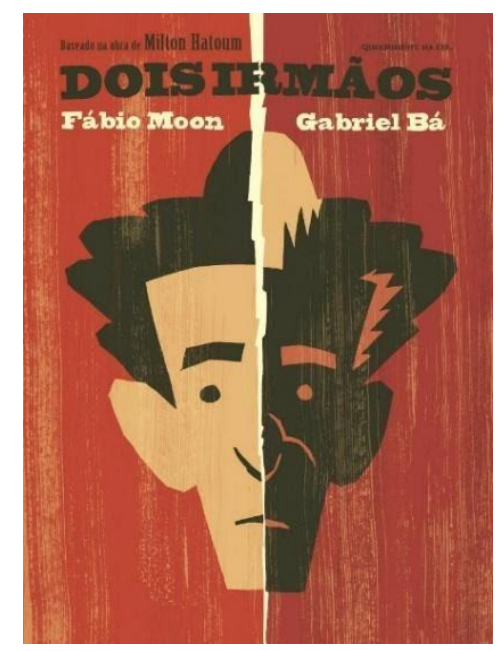

MOON, Fábio; BÁ, Gabriel. Dois irmãos: baseado na obra de Milton Hatoum. São Paulo: Quadrinhos na Cia, 2015.

1. Vocês já viram ou conhecem esse livro?

2. Observando o título e a capa, o que eles nos sugerem sobre o livro?

3. Que relação há entre o primeiro e o segundo livro?

4. Podemos dizer de quem são as figuras retratadas na capa? Qual a diferença entre elas?

5. Pelos rostos é possível dizer se há alguma tensão entre eles?

6. Qual a cor predominante na capa? Você acha que pode ter uma intenção na escolha dessa cor? Qual seria?

7. Há uma rachadura no meio da capa. Por que motivo ela estaria ali?

$\rightarrow$ Falar sobre os autores dos livros, projetando a imagem no datashow, tanto do livro quanto do autor.

8. Você tem alguma informação sobre o autor do primeiro livro? Como é o nome dele? 


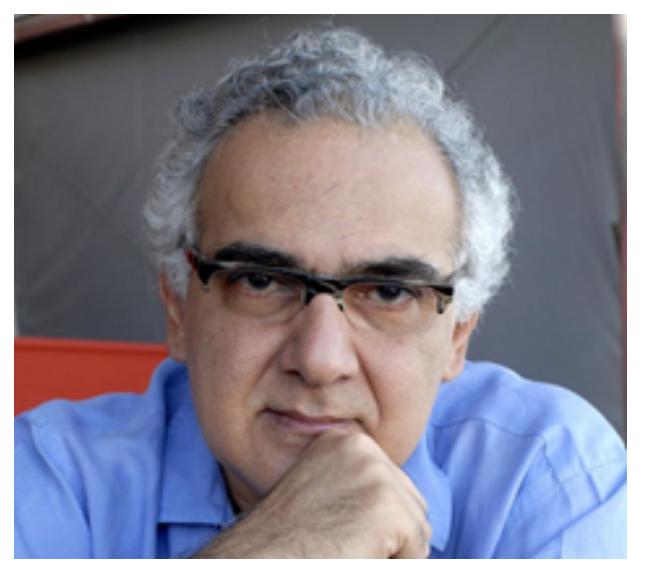

CASARIN, Rodrigo. Milton Hatoum, da literatura à política. Disponível em:

http://revistasentido.com/milton-hatoum-da-literatura-a-politica/. Acesso em: 05 de agosto de 2020.

Milton Hatoum nasceu em 1952, em Manaus (Amazonas), onde passou a infância e uma parte da juventude. Morou em Brasília, em São Paulo, viajou como bolsista para a Espanha, onde morou em Madri e Barcelona. Depois passou três anos em Paris, onde estudou literatura comparada na Sorbonne (Paris III). Autor de quatro romances premiados, sua obra foi traduzida em doze línguas e publicada em catorze países.

Em 1989, seu primeiro romance Relato de um certo Oriente, publicado pela editora Companhia das Letras, ganhou o prêmio Jabuti de melhor romance. Em 2000 publicou o romance Dois irmãos (prêmio Jabuti - $3^{\circ}$ lugar na categoria romance/ indicado para o prêmio IMPAC-DUBLIN), eleito o melhor romance brasileiro no período 1990-2005 em pesquisa feita pelos jornais Correio Braziliense e O Estado de Minas. Em 2001, foi um dos finalistas do Prêmio Multicultural do Estadão, por conta da publicação do em Dois Irmãos. Em 2005, seu terceiro romance, Cinzas do Norte, obteve o Prêmio Portugal Telecom, Grande Prêmio da Crítica/APCA-2005, Prêmio Jabuti/2006 de Melhor romance, Prêmio Livro do Ano da CBL, Prêmio BRAVO! de literatura. Em 2008, recebeu do Ministério da Cultura a Ordem do mérito cultural.

Todos os seus livros foram publicados no Brasil pela editora Companhia das Letras, cujas vendas ultrapassam trezentos mil exemplares. Sua obra já foi traduzida em 12 línguas e publicada em 14 países. As informações podem ser pesquisadas no próprio site. Desde 1998, mora em São Paulo, onde é colunista do Caderno 2 (O Estado de São Paulo).

Disponível em: http://www.miltonhatoum.com.br/biografia/a-historia-do-autor. Acesso em: 05 de agosto de 2020. Adaptado. 
9. De acordo com o site da Infoescola, Milton Hatoum, o escritor que estamos estudando, tem ascendência libanesa. Você sabe qual a diferença entre descendência e ascendência?

10. Agora que sabemos um pouco sobre o autor, de onde é o lugar desenhado na capa do livro? Por que você chegou a essa conclusão?

11. Já ouviram falar sobre os autores da história em quadrinhos? (Depois dos comentários, mostrar a breve biografia e a imagem).

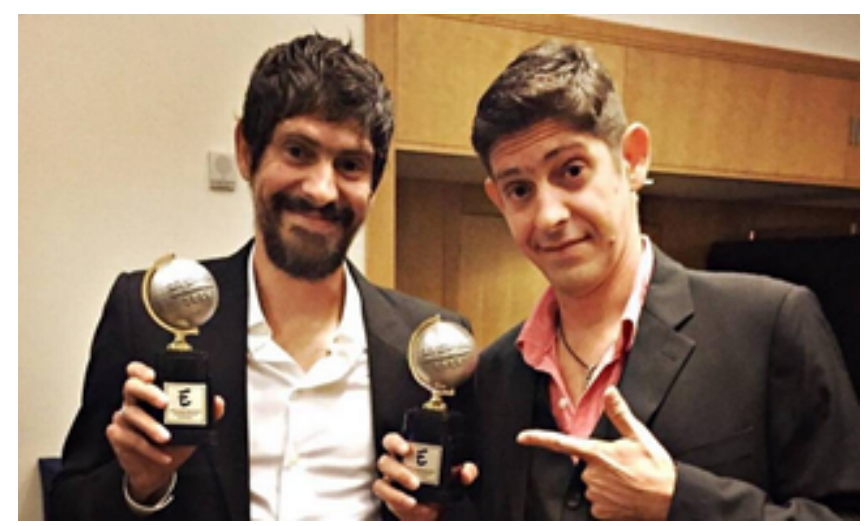

Imagem disponível em: oglobo.globo.com/ Acesso em: 05 de agosto de 2020.

São irmãos gêmeos e nasceram em 1976, em São Paulo. Publicaram seu primeiro fanzine de quadrinhos em 1993. Formados em Artes Plásticas, criaram em 1997 o fanzine 10 Pãezinhos, que recebeu o prêmio HQ Mix de melhor fanzine e de artistas revelação em 2000, ano em que lançaram seu primeiro livro, O Girassol e a Lua. Há quase vinte anos, os dois têm produzido quadrinhos para o mercado brasileiro e internacional e seus trabalhos já foram publicados em doze idiomas. Em 2008, O alienista, sua adaptação do clássico de Machado de Assis, recebeu um prêmio Jabuti.

MOON, Fábio. BÁ, Gabriel. Dois irmãos: baseado na obra de Milton Hatoum. São Paulo: Quadrinhos Na Cia, 2015.

12. Você sabe o que é um fanzine?

A palavra fanzine nasceu da redução fônica da expressão fanatic magazine. Ela provém da combinação do final do vocábulo 'magazine', que tem o sentido de 
'revista', com o início de 'fanatic'. Trata-se de um veículo editado por um fã, seja de graphic novels, obras de ficção científica, ou de poemas, músicas, filmes, vídeo-games, entre outras temáticas incorporadas por estas publicações. Enfim, são elaboradas por admiradores de certo assunto para pessoas que compartilham a mesma paixão. Eles podem ser peritos neste campo ou simples entusiastas.

SANTANA, Ana Lúcia. Fanzine. Disponível em: https://www.infoescola.com/curiosidades/fanzine/. Acesso em: 04 de fevereiro de 2020.

Devidamente apresentados às obras e aos autores, os alunos passariam ao primeiro capítulo da obra de Milton Hatoum, esclarecendo-se que, no momento apropriado, haveria a intercalação entre a obra de Hatoum e os quadrinhos de Moon e Bá.

\section{Terceiro momento: leitura}

Rildo Cosson afirma que nessa etapa precisa-se acompanhar a leitura proposta, uma vez que "a leitura escolar precisa de acompanhamento porque tem uma direção, um objetivo a cumprir, e esse objetivo não deve ser perdido de vista" (COSSON, 2018, p. 62). Esta etapa percorrerá todo o trabalho com a leitura da obra Dois irmãos, de Milton Hatoum, e a adaptação em quadrinhos de Fábio Moon e Gabriel Bá. Capítulos serão oferecidos através de xerox para o acompanhamento da história em sala ou fora dela, por se tratar de uma obra muito extensa para o trabalho somente em sala de aula. Neste caso, Cosson sugere que se façam intervalos que serão como "(...) um diagnóstico da etapa da decifração no processo de leitura" (Idem, p. 64). Esse acompanhamento torna-se importante para que a intervenção seja alcançada de forma mais eficiente.

Aula 3 - 6 aulas de 50 minutos. Capítulo 1 - Livro de Milton Hatoum.

$\rightarrow$ A professora explicaria que, antes de começarem a leitura, deveriam escrever em seus cadernos de leitura uma frase, iniciando dessa forma: "Família para mim (...)". Seriam convidados a compartilhar o que escreveram em turma, mas não seriam forçados a isso para que não se sentissem obrigados a escrever algo que não pensam. 
$\rightarrow$ Antes de iniciar a leitura das primeiras páginas, gostaria que cada um pensasse e escrevesse no caderno de leitura sobre qual é o significado de família.

$\rightarrow$ Compartilhamento da escrita sobre família.

$\rightarrow$ Leitura das páginas 11 e 12 do livro de Milton Hatoum, retratando a morte de Zana. A professora faria a leitura em voz alta, fazendo as perguntas no final, que deveriam ser respondidas de forma oral.

1. Esta parte inicial da obra que vamos ler traz um fato antecipado sobre a personagem Zana. O que aconteceu com a personagem?

2. Pelo trecho lido, como podemos caracterizar esta personagem?

3. Quais os lugares citados pelo narrador de onde Zana veio e onde morava?

4. De quem são os vultos que Zana vê? Dá para saber se eles estão vivos ou mortos?

5. Qual o filho que Zana espera o retorno?

6. A pergunta que ela faz em árabe para a filha e uma amiga dá a entender algo sobre o relacionamento entre os filhos de Zana?

7. É possível saber quem é o narrador desta história?

8. Há alguma ligação entre esses acontecimentos e a epígrafe de Drummond?

$\rightarrow$ Entregar capítulo 1, porém, só até a página 28, quando haveria uma pequena pausa na leitura deste excerto para questionamentos. Em seguida, fazer as perguntas abaixo, sendo algumas respondidas no caderno de leitura. 
1. Os nomes não são tão conhecidos como os nossos: Pedro, Maria, Luís... Você conhece pessoas com nomes muito diferentes? Sabe se seu nome tem algum significado e qual é? Vamos descobrir os significados de alguns nomes da nossa história. Vamos tentar relacionar os nomes aos seus significados e, no final da leitura de nossa obra, confirmar se os nomes refletem as personagens. (Esta questão precisa ser respondida por escrito, pois será retomada no final).

2. Os significados serão trocados para que façam a correlação.

Omar = "o que tem uma vida longa", "homem cheio de vida", "homem ilustre pela riqueza".

Halim = Meigo .

Rânia = "Conquistadora", "vencedora", "aquela que triunfa", "bem sucedida".

Domingas = Significa "do Senhor", "a que pertence ao Senhor"; deriva de domingo, ou seja, "o sétimo dia, quando Deus descansou da criação do mundo". Por analogia, significa "descanso".

Lívia = Significa "pálida", "lívida" ou "clara".

Dália = Significa "do vale" ou "bela flor mexicana". A interpretação literal deste nome pode ser entendida como "aquela que pertence ao vale".

Disponível em: https://www.dicionariodenomesproprios.com.br/busca.php?q=abbas. Acesso em: 10 de janeiro de 2020.

COSTA, Renata. Como surgiram os nomes dos dias da semana. Disponível em: https://novaescola.org.br/conteudo/175/como-surgiram-os-nomes-dos-dias-da-semana. Acesso em: 03 de outubro de 2020. Adaptado.

3. Há neste trecho alguma palavra que você desconheça e precise averiguar no dicionário? Quais são? Vamos anotá-las no caderno.

4. Yaqub para de frente para a parede do bar e "mija". Por que ele fez isso na rua? É algo comum? O que esse fato mostra?

5. Halim preocupava-se com o fato de os filhos gêmeos terem sido separados. É possível adivinhar o motivo dessa separação? O que levaria um pai a separar dois irmãos? 
6. Quando os gêmeos completaram 13 anos, o pai queria enviar os dois para o Líbano. A mãe, porém, convenceu o pai de enviar somente Yaqub. Como você acha que ele se sentiu? E o outro irmão, Omar?

7. Você tem alguma informação sobre o Líbano? (Provavelmente os alunos não terão muitas informações sobre o lugar. Falar algo da cultura, como beijar o rosto do pai - ou de um amigo, ver homens andando de mãos dadas, não se pode tirar fotografias de todos os lugares etc)

8. Quando alguém diz para Zana que Yaqub era mais altivo que o irmão, ela responde: "Nada disso, são iguais, são gêmeos, têm o mesmo corpo e o mesmo coração" (HATOUM, 2000, p. 23). Você pensa assim como Zana sobre gêmeos? Como você interpretaria a relação entre esses irmãos gêmeos?

9. Yaqub tem algo no rosto que o diferencia de seu irmão Omar. O que era?

10. (Haverá uma pequena pausa aqui. Estimular os alunos a falarem sobre a marca no rosto de Yaqub. Perguntas serão feitas como: Você tem alguma marca em seu corpo que traga lembranças? São lembranças boas ou ruins? Como você adquiriu essa marca? Aguardar os comentários. Neste ponto, permitir que todos que queiram falar sejam ouvidos e prosseguir com a leitura).

11. Qual a provável história dessa marca? O que teria acontecido com ele para ter uma marca no rosto?

\section{$\rightarrow$ Dar o capítulo 1 restante: p. 29 a 45.}

12. "A cicatriz já começava a crescer no corpo de Yaqub" (HATOUM, 2000, p. 28). Que "cicatriz" é essa? Você já soube de alguém que teve uma cicatriz que "cresceu pelo corpo"? O que isso quer dizer?

13. Quais as pistas que a narrativa fornece dos sentimentos de Yaqub?

14. Os pais não concordavam sobre a criação dos gêmeos. Como você analisa a postura da mãe e do pai até agora?

15. Já podemos saber que tipo de narrador tem essa história? 
16. Aconteceu um fato marcante na escola dos gêmeos que culminou na expulsão de um deles. Quem foi expulso e por quê? Você concorda com essa atitude tomada pela direção da escola? Por quê?

17.0 que se espera como reação dos pais diante do fato de uma expulsão da escola? Qual a atitude dos pais diante do ocorrido?

18. Há um ditado popular que diz: "Se conselho fosse bom ninguém dava vendia". Dar ou receber conselhos é válido? Por quê? Bolislau dá um conselho a Yaqub. $\mathrm{O}$ que você acha dele?

19. Uma mulher entra na sala da família de Halim para se despedir de Yaqub. Quem é ela? Como foi a despedida?

Aula 4 - 2 aulas de 50 minutos. Capítulo 2 (seria fornecido para leitura em casa as páginas 47 - 57 do livro de Hatoum, bem como as perguntas sobre este capítulo)

$\rightarrow$ Em sala de aula, os alunos sentariam em círculo para debater o capítulo 2 lido e já respondido no caderno de leitura.

$\rightarrow$ Roteiro de leitura para o capítulo 2 a ser respondido por escrito em casa. As respostas seriam compartilhadas na próxima aula. A professora deve abordar o rompimento da história que vem sendo contada no capítulo 1 , para a fase inicial da vida de alguns personagens, no caso, quando Halim conheceu a esposa, a fim de que o aluno perceba que o narrador está utilizando fatos da memória, trazendo um enredo não linear.

1. Quem é Galib?

2. O que era o Biblos?

3. Como Halim conheceu o Biblos? 
4. Halim estava entusiasmado com Zana e queria comprar-lhe um presente. O que ele quis comprar? Mas o que deu a Zana, de fato, convencido pelo amigo Abbas? Você daria valor a um presente assim?

5. Ele entrega o presente para Zana? O que acontece?

6. Como Halim pede Zana em casamento? Quantos anos Zana tinha? Há uma idade ideal para se casar? Explique seus motivos.

7. Quais as condições para o casamento acontecer?

8. Para onde Galib foi após a lua de mel de Halim e Zana? O que aconteceu com Galib?

9. Você já se trancou no quarto por algum motivo? Qual? Quantas semanas Zana ficou trancada no quarto?

10. Halim está contando sua história para quem?

11. O capítulo 2 fala de Galib, do Biblos e de Zana; o capítulo 1 fala do retorno de Yaqub para Manaus; já o 3, fala das cartas de Yaqub que chegavam de São Paulo. Podemos dizer que os capítulos estão em ordem cronológica? Por quê?

12. Ao ler o capítulo 2, percebemos que há um corte na história que vem sendo contada no capítulo 1. Por que você acha que isso aconteceu? Há uma explicação para a história avançar e retroceder desta forma?

Aula 5 - 2 aulas de 50 minutos. Capítulo 3 - Livro de Milton Hatoum. Leitura em voz alta dividida entre os alunos.

$\rightarrow$ Antes de passar para a leitura do capítulo 3, os alunos escreveriam a diferença de vida entre a metrópole e a vida no interior. Para isso, deveriam responder às perguntas abaixo que seriam coladas no caderno de leitura. 
1. Você já foi a alguma grande cidade? Qual? Como foi?

2. O que você prefere: cidade grande (metrópole) ou interior? Por quê?

3. Quais as oportunidades que cada um desses lugares oferece?

4. Qual será a preferência dos irmãos gêmeos? Eles moravam em uma metrópole?

$\rightarrow$ Seria dado o capítulo para que a turma fizesse a leitura em voz alta; cada aluno lendo uma parte do texto.

$\rightarrow$ As perguntas abaixo seriam feitas oralmente para dar continuidade ao capítulo em estudo.

1. Yaqub foi para uma cidade grande e começou a lecionar matemática. Quais outros fatos importantes vocês destacariam neste capítulo?

2. Quem era Domingas? Como ela entrou na família de Halim?

3. Na página 61 há um ditado popular: "Ele se sofisticava, preparando-se para dar o bote: minhoca que se quer serpente (...)". Em sua opinião, o que isso significa? Por que usar o símbolo da serpente?

4. Quando os gêmeos nasceram, Omar ficou aos cuidados da mãe e Yaqub de Domingas. Por que isso aconteceu? O que você acha disso?

5. Como Halim viu a chegada dos filhos?

6. Domingas confessa ao narrador que era "louca para ser livre". Que tipo de liberdade ela desejava?

7. Halim sai de madrugada de pijama e descalço. Que fato desencadeou essa fuga?

Aula 6 - 4 aulas de 50 minutos. Capítulo 4 - História em quadrinhos de Fábio Moon e Gabriel Bá. Leitura silenciosa.

$\rightarrow$ A professora explicaria que continuariam a ler a história, mas em quadrinhos. Receberiam o capítulo 4 integralmente para leitura silenciosa e responderiam 
às perguntas que seriam fornecidas através de xerox para colagem no caderno de leitura.

$\rightarrow$ Após a leitura, formariam grupos e compartilhariam as respostas dadas para averiguar se todos tiveram o mesmo entendimento. A professora circularia pelos grupos a fim de auxiliar e verificar o progresso do trabalho.

1. Quem são os personagens deitados no sofá?

2. Observando a expressão da moça, no segundo quadrinho, o que ela revela?

3. De quem é a figura no alto da escada e que atitude toma? Por que as figuras estão em planos diferentes? O que isso pode significar?

4. Quem é a criança que assiste à cena?

5. O que aconteceu com o personagem que estava deitado no sofá?

6. É possível perceber pelas expressões e pelos poucos escritos: "AAAAA, PAAAAAAAA, TAPAAFF, POF", os sentimentos?

7. Por que não há texto nesta página? A linguagem não verbal carrega o mesmo sentido da verbal? Por quê?

8. Yaqub faz um anúncio muito importante à família através de um telegrama. Você sabe o que é um telegrama? O que ele anuncia?

9. Que outra notícia Zana recebe sobre o Omar?

10. Quem era a Mulher Prateada?

11. Com que intenção Zana chama Dália para Ihe ajudar no final da festa?

12. O que Zana oferece para Dália e sua família?

13. O que acontece com Omar após a passagem de Dália por sua vida?

14. O filho de Domingas ingressa no Galinheiro dos Vândalos. O que era esse lugar e por que esse nome? 
15. As imagens são feitas em preto e branco, sendo algumas páginas mais escuras e outras mais claras. Você acredita que isso tem alguma relação com o desenvolvimento da narrativa? Por que os tons são diferentes?

Aula 7 - 4 aulas de 50 minutos. Capítulo 5 - História em quadrinhos de Moon e Bá.

$\rightarrow$ A professora dirigiria este momento. A história seria colocada em datashow, assim como as perguntas. Algumas seriam escritas no caderno de leitura.

1. O filho de Domingas tem dúvidas sobre quem é o seu pai. Quem você acha ser o pai dele?

2. O que vocês entendem por ironia? Yaqub, quando questionado por que não levou a esposa para visitar a família, responde: "O outro filho vai te dar uma nora e tanto. Uma nora tão exemplar quanto ele". Há ironia nessa resposta? O que ele quis dizer com isso?

3. Quando Yaqub relembra os lugares da infância com Domingas, fala com saudosismo até que partiu para o Líbano. Há algum ressentimento na fala dele? Por quê?

4. Quando Talib pergunta se Yaqub sentia saudades do Líbano, ele responde: "Que Líbano?". Por que o personagem dá essa resposta?

5. Yaqub diz que não se esqueceu da língua nem de outra coisa, mas não completa a frase. Que "outra coisa" seria?

a) Ainda falando dessa "outra coisa" que Yaqub não pode esquecer, ele termina a frase com uma reticência. As reticências neste caso são usadas para indicar uma ideia que se prolonga ou interromper uma ideia ou um pensamento? O que você acha? Por quê? 
b) Após todos terem ido embora, Yaqub permanece debaixo da seringueira. "Ele e sua frase incompleta. A reticência, o ruído de sua vida". O que é um ruído para você?

c) O que seria o "ruído" na vida de Yaqub?

d) Como podemos entender então a última frase: "A reticência , o ruído de sua vida"?

7. Halim conta para o filho de Domingas que Omar fez algo muito grave em São Paulo, que deixou Yaqub muito aborrecido. O que Omar fez?

Aula 8 - 2 aulas de 50 minutos. Capítulo 6 - História em quadrinhos. Leitura em duplas.

$\rightarrow$ As duplas receberiam uma cópia para a leitura. Após um tempo estipulado, a professora faria as perguntas e os alunos dariam respostas orais.

1. Você já levou alguém muito importante para você para almoçar em sua casa? Como foi a reação da sua família?

2. Quem Omar leva para jantar em sua casa? Qual a importância dele?

3. O que o carro de Omar revela para a família, principalmente para Zana?

4. O que Zana descobre sobre o novo amigo de Omar?

5. Quem era Pau-Mulato?

6. O que Omar fez quando sua mãe descobriu sobre seus negócios e suas saídas misteriosas?

7. Omar diz para a mãe: "A senhora tem o outro filho que só dá gosto e tem bom posto". Há algum tipo de ironia nessa fala? Por quê? O que ele quis dizer com essa frase?

8. Omar retorna para casa, para alegria de Zana. Como acontece essa volta? 
9. Quais os adjetivos que Halim dá a Omar? Até agora, pelo que você leu, concorda com esses adjetivos? Por quê?

10. Como pais, você faria a mesma coisa que eles fizeram por Omar? Se pudesse mudar a história que desfecho você daria a Omar, olhando do ponto de vista de Halim e de Zana?

Aula 9 - 4 aulas de 50 minutos. Capítulo 7 - Livro de Hatoum (leitura em casa) e o episódio 7 do seriado lançado pela Globoplay (em sala de aula).

$\rightarrow$ A importância de assistir a esse capítulo na TV é por ele retratar cenas da vida real da época da ditadura mescladas à ficção, saindo do abstrato para o concreto, além de oferecer a oportunidade de outra leitura através desse outro gênero textual, uma vez que para cada gênero há uma nova leitura. Desta forma, os alunos entenderiam melhor o que foi esse momento da História Brasileira e, no enredo, compreenderiam a prisão e a morte de um professor que é um dos personagens, teriam uma visão diferenciada dos acontecimentos.

$\rightarrow$ A leitura do capítulo 7 de Hatoum seria feita em casa. Em sala, os alunos assistiriam ao episódio do seriado (também o capítulo 7) baseado no livro de Hatoum que contém aproximadamente 49 minutos. A minissérie lançada no ano de 2017 totaliza 10 capítulos, foi dirigida por Luiz Fernando Carvalho e roteirizada por Maria Camargo. No final, os discentes falariam das diferenças encontradas entre o filme e o capítulo do livro.

$\rightarrow$ A professora abordaria a liberdade de criação que um diretor cinematográfico tem em modificar alguma coisa do original. 
$\rightarrow$ As perguntas abaixo serviriam de base para a discussão e seriam feitas e respondidas oralmente.

1. Você já ouviu falar em ditadura? Sabe o que foi?

2. Você sabe o que é liberdade de expressão? Por que ele foi condenado nesta época?

3. Quem eram os mais perseguidos neste movimento?

4. Há, no capítulo 7, alguma referência à ditadura? Em que momento?

5. O que aconteceu com o filho de Domingas quando saiu com Yaqub para fotografar os edifícios e monumentos? Por que ele ficou assim?

6. Há um episódio em que Omar, nu, arranhava uma árvore e gritava de dor. Por que ele fazia isso? Isso foi retratado no filme?

7. Você tem conhecimento do que é gonorreia e como se pega?

8. O que mais podemos destacar de importante neste capítulo que não foi para o seriado?

Cap. 7 - Globoplay - Disponível em: https://globoplay.globo.com/v/5578824/programa/ . Cap. 07. Acesso em: 19/03/21.

Aula 10 - 4 aulas de 50 minutos. Capítulo 8 - Livro de Hatoum. Leitura e reelaboração da história por grupos. Intertextualidade com a Bíblia e Machado de Assis.

$\rightarrow$ A turma seria dividida em grupos para a leitura deste capítulo. Cada grupo receberia uma numeração: grupo 1, 2 e assim por diante.

$\rightarrow$ Um representante de cada grupo seria eleito para ser o porta-voz. O grupo 1 seria o primeiro a contar sua parte, pois corresponderá ao início da história; o grupo 2 continuaria a história e assim por diante, até que todo o capítulo tenha sido recontado pelos grupos. 
$\rightarrow$ As perguntas abaixo ajudariam a focar nas partes principais e seriam feitas oralmente pela professora após a apresentação dos grupos, caso não tenham abordado esses questionamentos.

1. Na página 215 (HATOUM, 2000), lemos: "Só faltou trocar os braços por asas. O querubim. O santinho da casa". Sobre quem o narrador fala? Você concorda com essa afirmação?

2. O comportamento de Omar quando seu pai morre foi considerado normal? O que ele demonstrou com o gesto que tomou?

3. Talib entra em cena e deixa um recado sobre o corpo. Que recado foi esse? Por que era necessário fazer isso? Isso é comum?

4. Yaqub envia uma coroa de flores e um epitáfio. O que é isso, você sabe? O que dizia a mensagem?

5. Qual advertência Zana faz a Omar após a morte de Halim?

6. Após algum tempo, Omar leva outro visitante para casa. Quem era ele e o que queria?

7. Qual o plano de Zana para tentar unir os irmãos? O que você faria no lugar de Zana?

8. Zana afirma não ser mãe de Caim e Abel (HATOUM, 2000, p.228). Por quê? Você conhece essa história e de onde ela é? O que ela tem a ver com a nossa narrativa?

9. Existe uma história chamada Esaú e Jacó, de Machado de Assis. Você já leu essa narrativa? O que ela tem em comum com Caim e Abel?

10. Yaqub responde a carta da mãe. Ela ficou feliz com a resposta?

11. Como você interpreta a relação de Rânia com os irmãos?

12. O que aconteceu com Yaqub quando Omar chegou? 
13. O que de fato desencadeou a briga entre os irmãos?

14. Que acordo Rânia fez com Rochiram?

15. Observe os fragmentos de textos (disponibilizar os trechos através de xerox):

I. "Já o fato de se chamarem Pedro e Paulo indicava alguma rivalidade, porque esses dois apóstolos brigaram também. (...) Os gêmeos, não tendo o que fazer, iam mamando. Nesse ofício portavam-se em rivalidade, (...) cada qual então parecia querer mostrar que mamava mais e melhor. (...) Paulo era mais agressivo, Pedro mais dissimulado. (...) Vingaram-se a murro. A mãe ouviu e subiu apressada, contendo-os, mas já os achou arranhados e recolheu-se triste. Nunca mais acabaria aquela maldição de rivalidade? Brigavam sempre ambos, a propósito de tudo" (ASSIS, 2009, p. 14;16).

II. “(...) Eis que havia gêmeos no seu ventre. Saiu o primeiro, ruivo, todo ele como um vestido de pelo; e chamaram-lhe Esaú. Depois saiu o seu irmão, agarrada sua mão ao calcanhar de Esaú; pelo que foi chamado Jacó. (...) Cresceram os meninos; e Esaú tornou-se perito caçador, homem do campo; mas Jacó, homem sossegado, que habitava em tendas. (...) Esaú, pois, odiava a Jacó por causa da bênção com que seu pai o tinha abençoado, e disse consigo: Vêm chegando os dias de luto por meu pai; então hei de matar Jacó, meu irmão" (GÊNESIS, 25. 24- 27; 27. 41).

III. "Halim se assustou ao ver os dois dedos da parteira anunciando gêmeos. Nasceram em casa, e Omar uns poucos minutos depois. O caçula. O que adoeceu muito nos primeiros meses de vida. E também um pouco mais escuro e cabeludo que o outro. (...) O duelo entre os gêmeos era uma centelha que prometia explodir. (...) Então eu o avistei: mais alto que a cerca, o corpo crescendo, se agigantando, a mão direita fechada que nem martelo, o olhar alucinado no rosto irado. Arfava, apressando o passo. Quando gritei, Omar deu um salto, ergueu a rede e começou a socar Yaqub no rosto, nas costas, no corpo todo. (...) Ele chutava e esmurrava o irmão, xingando-o de traidor, de covarde" (HATOUM, 2000, p. 62; 66- 67; 233).

IV. "Conheceu Adão a Eva, sua mulher; ela concebeu e, tendo dado à luz a Caim, disse: Alcancei do Senhor um varão. Tornou a dar à luz um filho - a seu irmão Abel. Abel foi pastor de ovelhas, e Caim foi lavrador da terra. (...) Falou Caim com o seu irmão Abel. E, estando eles no campo, Caim se levantou contra o seu irmão Abel, e o matou" (GÊNESIS, 4.1- 2; 8). 
Responda:

a) O que há em comum entre os trechos lidos?

b) Você sabe de onde saíram esses trechos, de quais enredos?

c) Qual desses trechos você considera como o mais antigo?

d) Zana afirma não ser mãe de Caim e Abel (HATOUM, 2000, p. 228). Por quê? Você conhece essa história e de onde ela é? O que ela tem a ver com a nossa narrativa?

e) Existe uma história chamada Esaú e Jacó, de Machado de Assis. Você já leu ou ouviu sobre essa narrativa? O que ela tem em comum com Caim e Abel? (Sugere-se ao professor, em caso dos alunos não conhecerem o enredo, fazer um breve resumo da obra oralmente, para que se situem no contexto).

f) Quando "em um texto está inserido um outro texto anteriormente produzido" (KOCH e ELIAS, 2011, p. 86) chamamos de intertextualidade. Podemos dizer que esses trechos dialogam entre eles, ou seja, são intertextuais? Explique.

16. O que você acha que vai acontecer no próximo capítulo da narrativa Dois irmãos?

Aula 11 - 2 aulas de 50 minutos. Capítulo 9 - Livro de Hatoum.

$\rightarrow$ A professora faria a leitura do capítulo e os alunos acompanhariam. As perguntas seriam escritas no quadro e os alunos responderiam oralmente.

1. Domingas conta como foi o nascimento de seu filho e quem era seu pai. Foi um momento festivo para ela? Por quê? Quem é o pai?

2. Qual a atitude de Halim quando soube da gravidez de Domingas?

3. Que nome o filho de Domingas recebe? 
4. Zana se desfaz do cofre . Que lembranças lhe traziam esse objeto?

5. O que acontece com Domingas?

Aula 12 - 2 aulas de 50 minutos. Capítulo 10 - Livro de Hatoum. A leitura seria feita em sala e dividida entre a professora e os alunos. As respostas seriam escritas no caderno de leitura.

1. A expressão "filho de ninguém" se referia a quem? O que isso quer dizer?

2. Rânia pede um favor a Nael. Que favor foi esse?

3. O que acontece com Zana?

Aula 13 - 2 aulas de 50 minutos. Capítulo 11 - História em quadrinhos. Leitura em sala silenciosa.

$\rightarrow$ Os alunos responderiam somente à primeira pergunta no caderno de leitura. Só depois receberiam o capítulo 11 para responder às próximas perguntas de forma oral.

1. Em sua opinião, o que vai acontecer com alguns personagens como: Omar, Rânia e Yaqub? E com Nael? (Responder por escrito)

2. O que Yaqub fez que teve a desaprovação de Rânia?

3. Você concorda com o que Yaqub fez contra Omar? Se você estivesse em uma situação assim faria o mesmo?

4. Qual resposta Yaqub deu à sua irmã?

5. O que você faria no lugar de Yaqub? 


\section{Quarto momento: Interpretação}

Aula 14 - 4 aulas de 50 minutos. Capítulo 12 - História em quadrinhos para completar.

$\rightarrow$ A professora explicaria que receberiam o último capítulo da história com alguns quadros escritos e outros não e que deveriam completar conforme decidissem ser o final esperado.

$\rightarrow$ Antes, porém, responderiam às seguintes perguntas no caderno de leitura:

1. No início de tudo, no capítulo 1 , fizemos um exercício sobre o significado dos nomes, lembram-se? Vocês podem confirmar se os nomes de Halim, Omar e todos os outros que vimos realmente significam o que estava escrito? Explique sua resposta.

2. Que desfecho você acha ser mais apropriado para Omar? O que acontecerá com ele no final da nossa narrativa?

3. Agora você já sabe quem é o narrador da nossa história? Quem é?

4. Como o narrador conseguiu contar tudo o que lemos no enredo?

5. A história escrita por Milton Hatoum seguiu uma ordem certinha, com início, meio e fim? Foi linear ou não linear? Explique.

6. Que futuro estará reservado a Nael?

7. Será que Omar e Nael se reconciliarão? Por quê?

$\rightarrow$ Receberiam, em seguida, o último capítulo em HQ para criar um final de acordo com a visão pessoal do que aconteceu. 
HQ - EPÍLOGO (FÁBIO MOON E GABRIEL BÁ)
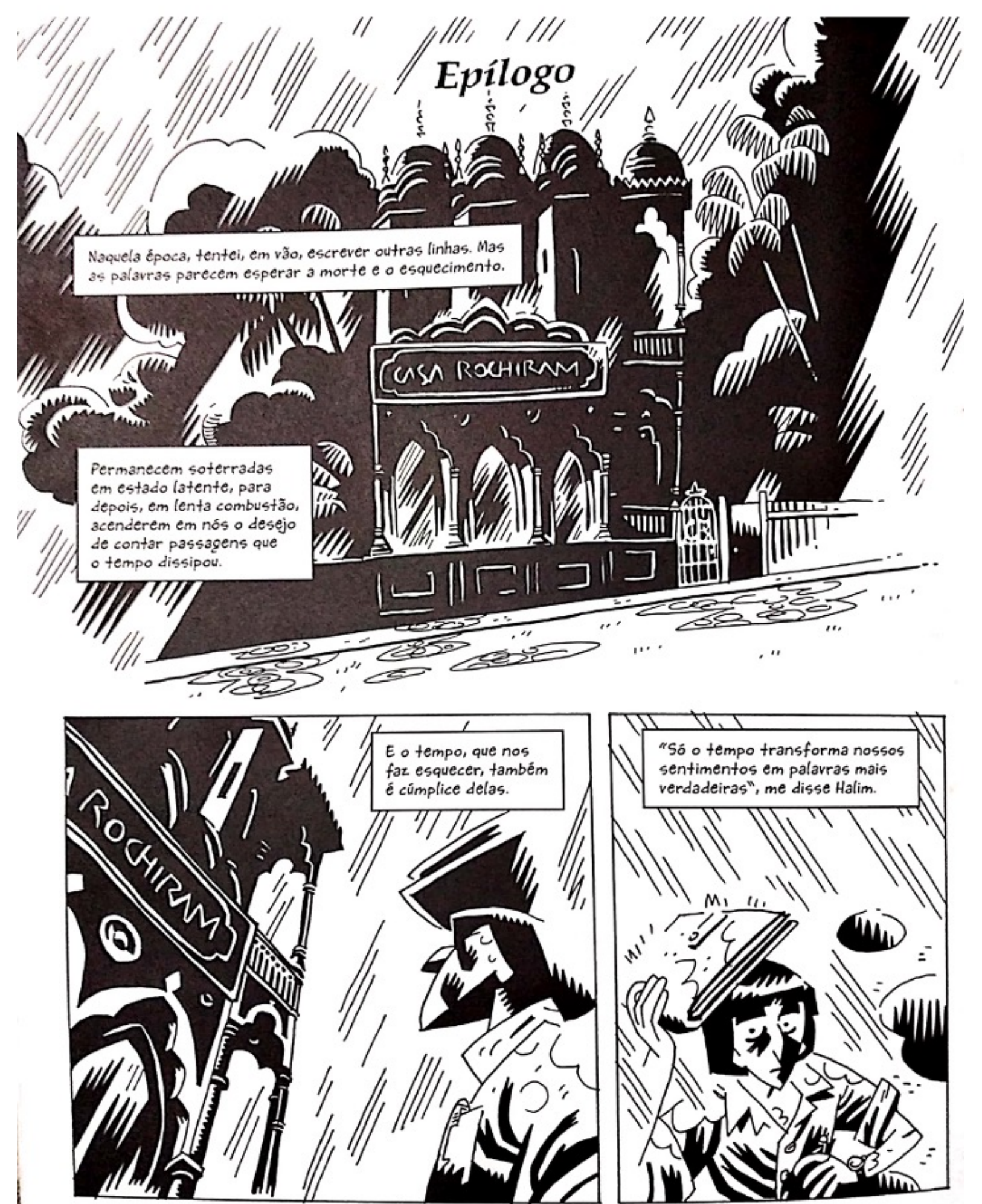

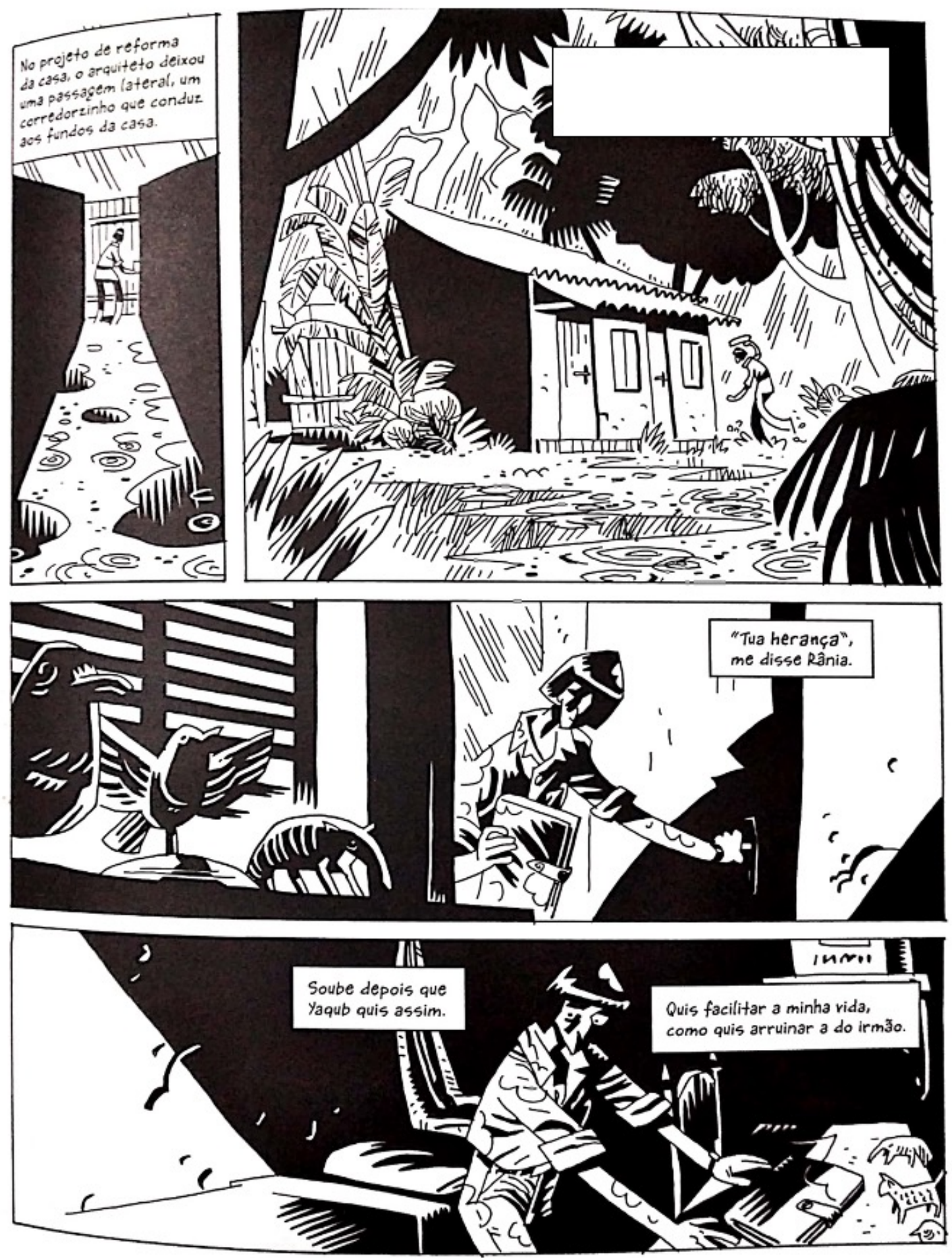

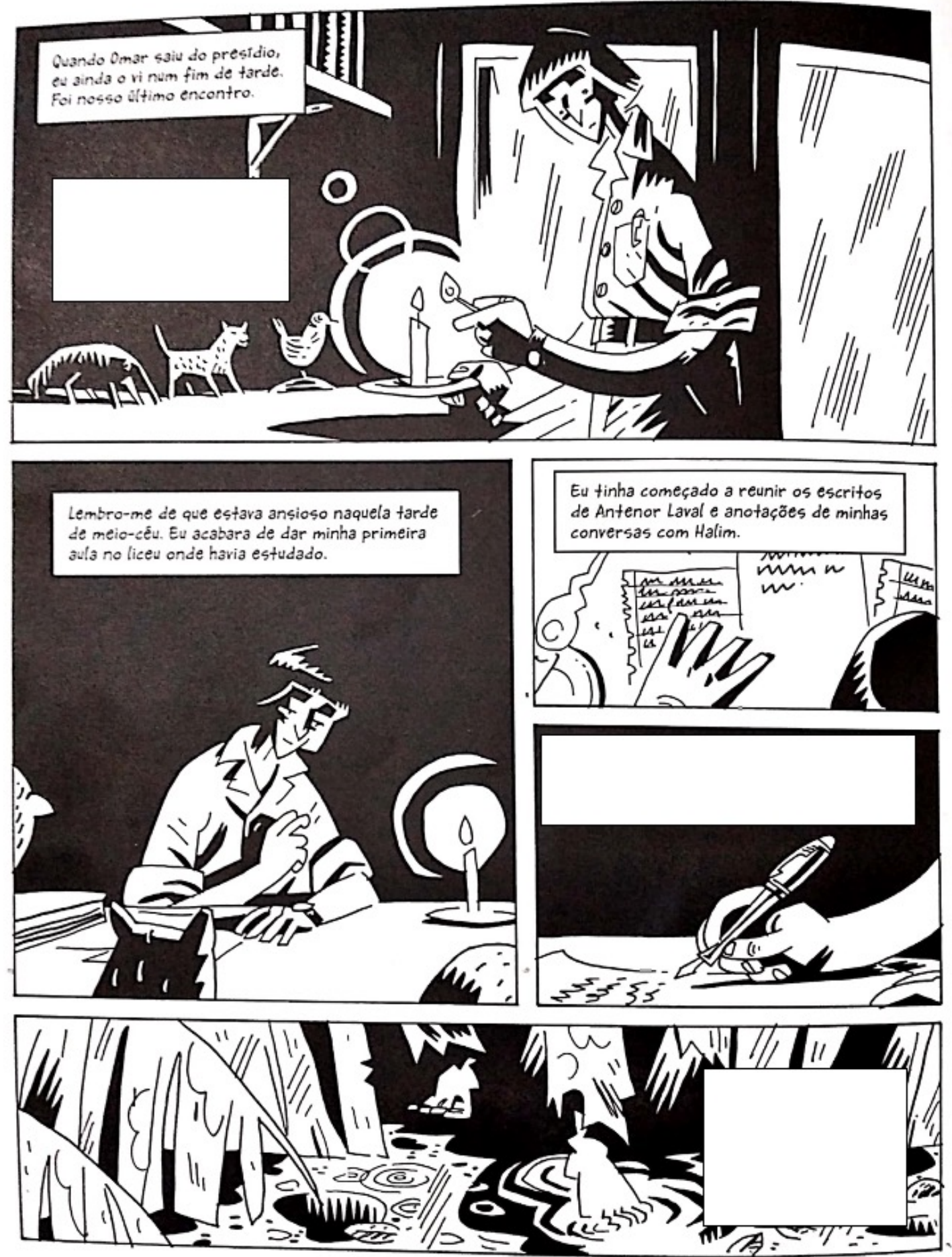

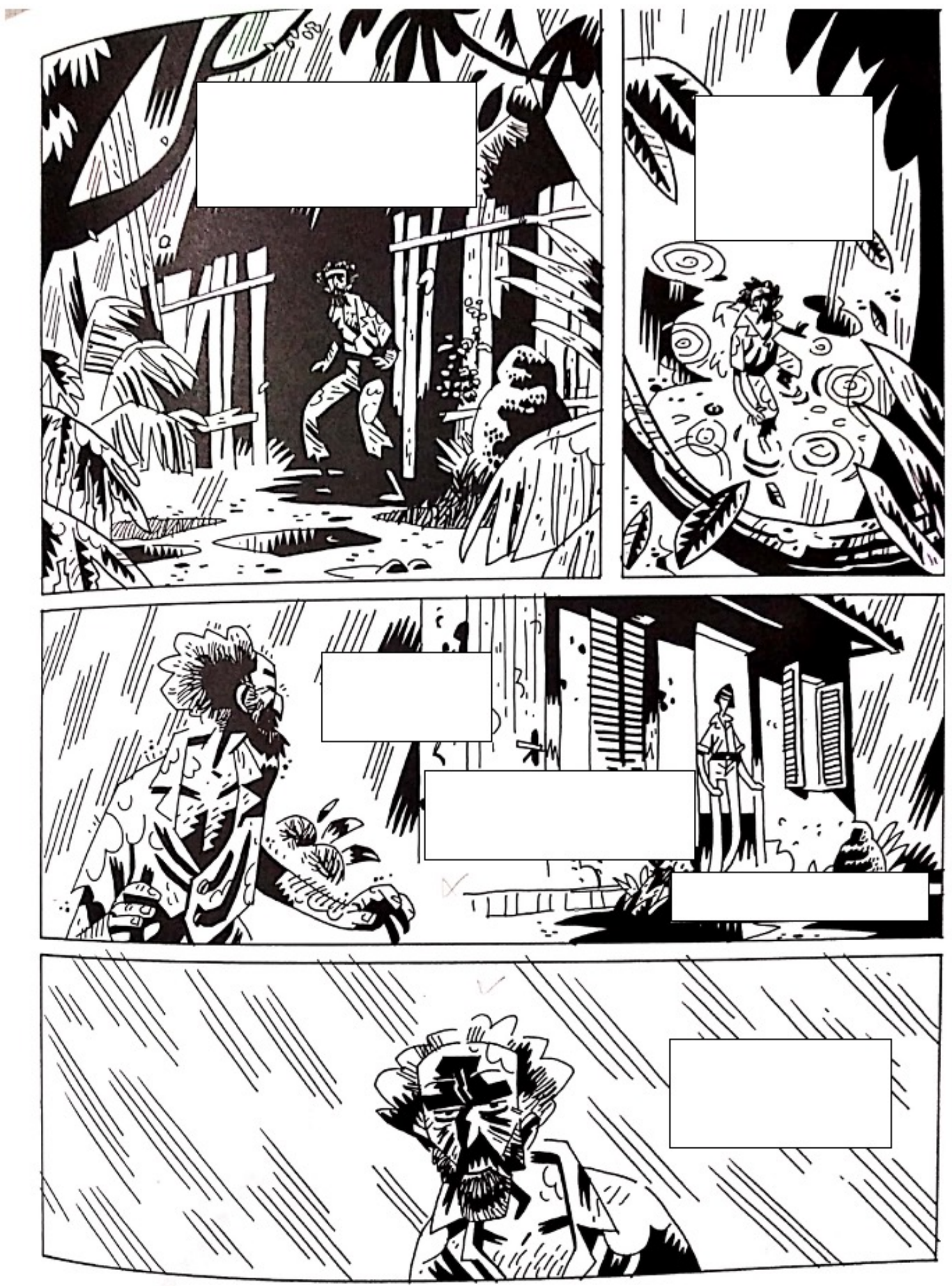

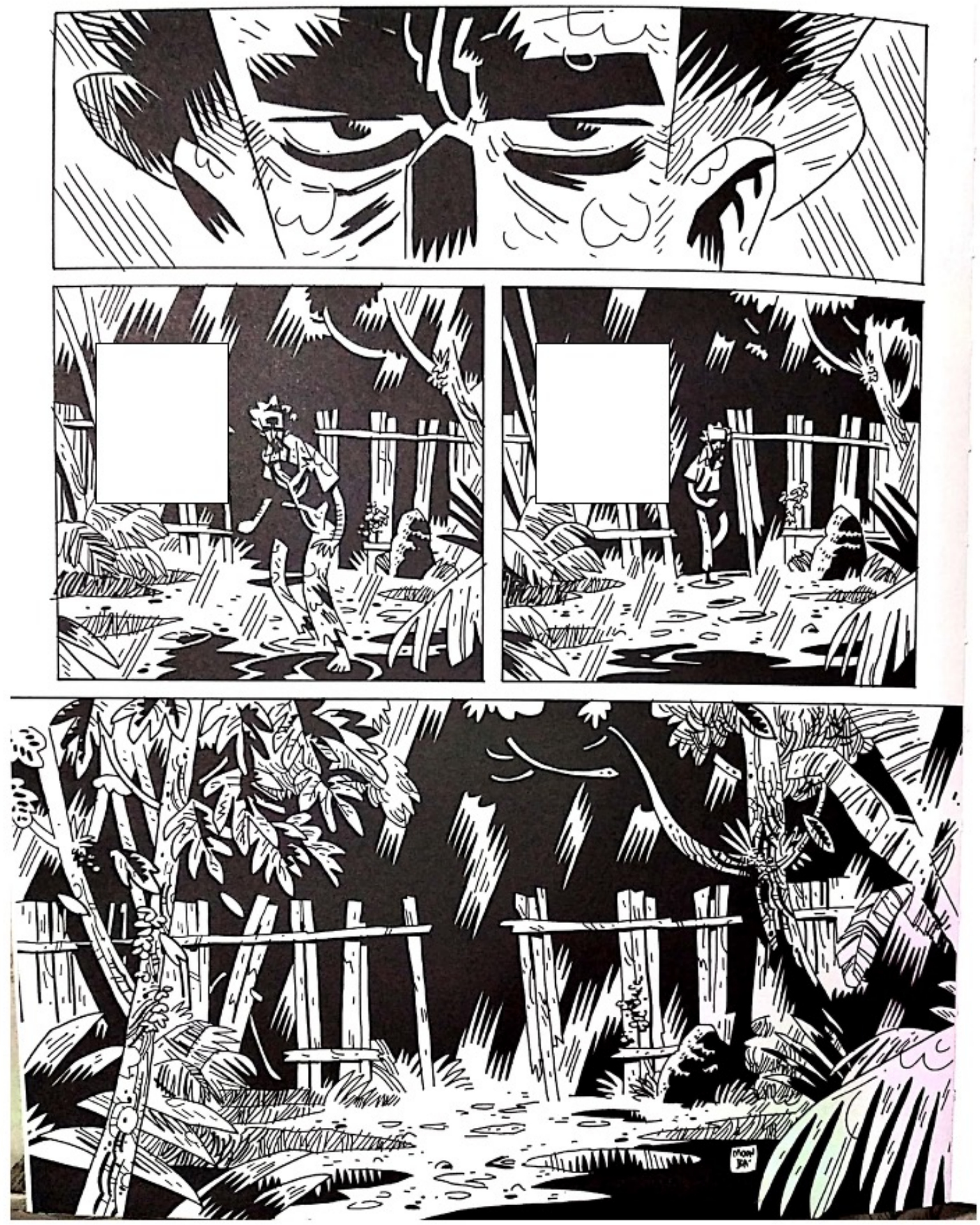
$\rightarrow$ Após todos terem escrito, haveria o momento de compartilhar os finais. Todos os alunos contariam sua versão final.

$\rightarrow$ Em seguida, a professora disponibilizaria, através de cópias, o final escrito no livro de Milton Hatoum a fim de que os alunos soubessem o que aconteceu no desfecho e pudessem comparar seus escritos com o do autor. Um aluno faria essa leitura.

\section{FINAL: CAPÍTULO 12 - LIVRO DE MILTON HATOUM (2000, p. 264 - 266)}

Naquela época, quando Omar saiu do presídio, eu ainda o vi num fim de tarde. Foi o nosso último encontro.

O aguaceiro era tão intenso que a cidade fechou suas portas e janelas bem antes do anoitecer. Lembro-me de que estava ansioso naquela tarde de meio-céu. Eu acabara de dar minha primeira aula no liceu onde havia estudado e vim a pé para cá, sob a chuva, observando as valetas que dragavam o lixo, os leprosos amontoados, encolhido debaixo dos outizeiros. Olhava com assombro e tristeza a cidade que se mutilava e crescia ao mesmo tempo, afastada do porto e do rio, irreconciliável com o seu passado.

Um relâmpago havia provocado um curto-circuito na Casa Rochiram. O bazar indiano tornara-se um breu na tarde sombria, coberta de nuvens baixas e pesadas. Entrei no meu quarto, este mesmo quarto nos fundos da casa de outrora. Trouxera para perto de mim o bestiário esculpido por minha mãe. Era tudo o que restara dela, do trabalho que Ihe dava prazer: os únicos gestos que lhe devolviam durante a noite a dignidade que ela perdia durante o dia. Assim pensava ao observar e manusear esses bichinhos de pau-rainha, que antes me pareciam apenas miniaturas imitadas da natureza. Agora meu olhar os vê como seres estranhos.

Eu tinha começado a reunir, pela primeira vez, os escritos de Antenor Laval, e a anotar minhas conversas com Halim. Passei parte da tarde com as palavras do poeta inédito e a voz do amante de Zana. la de um lado para o outro, e essa alternância - o jogo de lembranças e esquecimentos - me dava prazer. 
O toró que cobria Manaus, trégua na quentura do equador, me aliviava. Frutas e folhas boiavam nas poças que cercavam a porta do meu quarto. Nos fundos, o capim crescera, e a cerca de pau podre, cheia de buracos, não era mais uma fronteira com o cortiço. Desde a partida de Zana eu havia deixado ao furor do sol e da chuva o pouco que restara das árvores e trepadeiras. Zelar por essa natureza significava uma submissão ao passado, a um tempo que morria dentro de mim.

Ainda chovia, com trovoadas, quando Omar invadiu o meu refúgio. Aproximou-se do meu quarto devagar, um vulto. Avançou mais um pouco e estacou bem perto da velha seringueira, diminuído pela grandeza da árvore. Não pude ver com nitidez o seu rosto. Ele ergueu a cabeça para a copa que cobria o quintal. Depois virou o corpo, olhou para trás: não havia mais alpendre, a rede vermelha não o esperava. Um muro alto e sólido separava o meu canto da Casa Rochiram. Ele ousou e veio avançando, os pés descalços no aguaçal. Um homem de meia-idade, - Caçula. E já quase velho. Ele me encarou. Eu esperei. Queria que ele confessasse a desonra, a humilhação. Uma palavra bastava, uma só. O perdão.

Omar titubeou. Olhou para mim, emudecido. Assim ficou por um tempo, o olhar cortando a chuva e a janela, para além de qualquer ângulo ou ponto fixo. Era um olhar à deriva. Depois recuou lentamente, deu as costas e foi embora.

$\rightarrow$ Cumpre-se, com as últimas atividades, a quarta etapa da sequência básica de Cosson: a interpretação, quando os alunos começam a construir sentidos levando em conta a leitura feita até o momento e estão aptos a registrar o que inferiram para o final da história apresentada através da obra de Milton Hatoum. Com o auxílio dos quadrinhos de Fábio Moon e Gabriel Bá, os alunos desenvolvem seu final, a partir do entendimento construído para $\mathrm{O}$ enredo, tornando-se, desta forma, coparticipantes do texto. 


\section{Referências Bibliográficas}

AGAMBEN, Giorgio. O que é contemporâneo? e outros ensaios. Trad. Vinícius Nicastro Honesko. Chapecó, SC: Argos, 2009.

ANDRADE, Carlos Drummond de. Obra poética. Rio de Janeiro: Aguillar, 1993.

ANTUNES. Irandé. Aula de português: encontro e interação. São Paulo: Parábola Editorial, 2003. Editorial, 2005.

Lutar com palavras: coesão e coerência. São Paulo: Parábola Editorial, 2009.

Língua, texto e ensino: outra escola possível. São Paulo: Parábola Análise de textos: fundamentos e práticas. São Paulo: Parábola Editorial, 2010.

ASSIS, Machado. Esaú e Jacó. São Paulo: Rideel, 2009.

BAKHTIN, Mikhail. Estética da criação verbal. São Paulo: Martins Fontes, 2003.

BÍBLIA. A Bíblia Sagrada: Antigo e Novo Testamento. Trad. de João Ferreira de Almeida. Rio de Janeiro: Imprensa Bíblica Brasileira, 1992.

BORGES, Jorge Luis. Obras completas. São Paulo: Globo, 2000, v. 02.

BORTONI-RICARDO. Stella Maris. O professor pesquisador - introdução à pesquisa qualitativa. São Paulo: Parábola Editorial, 2008.

BRASIL. Parâmetros Curriculares Nacionais para o Ensino Fundamental (PCNs). Brasília: MEC/SEF, 1996.

. Base Nacional Comum Curricular (BNCC). Brasília: MEC, 2017.

CALVINO, Ítalo. Por que ler os clássicos. São Paulo: Companhia das Letras, 2007.

CÂNDIDO, Antônio. "O direito à Literatura". In: Vários Escritos. $4^{\mathrm{a}}$ ed. São Paulo: Duas Cidades, 2004.

COLOMER, Teresa. Andar entre livros: a leitura literária na escola. Trad. de Laura Sandroni. São Paulo: Editora Global, 2007.

COMPAGNON, Antoine. O demônio da teoria: literatura e senso comum. Belo Horizonte: Editora UFMG, 2001. 
UFMG, 2010 .

Os cinco paradoxos da modernidade. Belo Horizonte: Editora

COSSON, Rildo. Círculos de leitura e letramento literário. São Paulo: Contexto, 2014.

. Letramento literário: teoria e prática. São Paulo: Contexto, 2018.

DELEUZE, Gilles; GUATTARI, Félix. Kafka: por uma literatura menor. Belo Horizonte: Autêntica Editora, 2017.

DIKSON, Dennys. Da escrita para a escrita: aspectos e processos em retextualização. Recife: EDUFRPE, 2019.

DINIZ, Thaís Flores Nogueira; VIEIRA, André Soares (Orgs.). Intermidialidade e estudos interartes: desafios da arte contemporânea. Belo Horizonte: Rona Editora: FALE/UFMG, 2012.

DOIS IRMÃOS. Produção de Luiz Fernando Carvalho. Rio de Janeiro: Globoplay, 2017. Disponível em: globoplay.globo.com/dois-irmaos/t/JZJMXTZ9w8/ cap.07. Acesso em: 13 de fev. de 2020.

ELLIOT, T. S. Ensaios. São Paulo: Art Editora, 1989.

EVEN-ZOHAR, Itamar. "Teoria dos polissistemas". Trad. Luís Fernando Marozo, Carlos Rizzon e Yanna Karlla Cunha. In: Revista Translatio, v. 4, n. 5, pp. 2-21, 2013.

"O sistema literário". Trad. Marozzo, Luis Fernando e Yanna Karlla. In: Revista Translatio, v. 4, n. 5, pp. 22-45, 2013.

FAGUNDES, Tatiana Bezerra. "Os conceitos de professor pesquisador e professor reflexivo: perspectivas do trabalho docente". In: Revista Brasileira de Educação, v. 21, n. 65, abr-jun, 2016.

FREIRE, Paulo. A importância do ato de ler: em três artigos que se completam. São Paulo: Cortez, 1984.

HATOUM, Milton. Dois irmãos. São Paulo: Companhia das Letras, 2000.

HUTCHEON, Linda. Uma teoria da adaptação. Florianópolis: Ed. da UFSC, 2013.

ISER, Wolfgang. $\mathbf{O}$ ato da leitura. Trad. de Johannes Kretschmer. São Paulo: Editora 34, pp. 128-157, 1996.

KLEIMAN, Angela (Org.). Os significados do letramento: uma nova perspectiva sobre a prática social da escrita. São Paulo: Mercado das Letras, 1995.

$\mathrm{KOCH}$, I. V.; ELIAS, V. M. Ler e compreender os sentidos do texto. $3^{a}$ ed. São Paulo: Contexto, 2011. 
MARCUSCHI, L. A. Produção textual, análise de gêneros e compreensão. São Paulo: Parábola Editorial, 2008.

$\overline{\text { Cortez, } 2013 .}$

Da fala para a escrita: atividades de retextualização. São Paulo:

MCLOUD, Scott. Desvendando os quadrinhos. São Paulo: M. Books do Brasil Ltda., 2005.

. Desenhando quadrinhos. São Paulo: M. Books do Brasil Ltda., 2008.

MOON, Fábio; BÁ, Gabriel. Dois irmãos: baseado na obra de Milton Hatoum. São Paulo: Quadrinhos na Cia, 2015.

PAULINO, Graça; COSSON, Rildo. "Letramento literário: para viver a vida dentro e fora da escola”. In: ZILBERMAN, Regina; RÖSING, Tania (Org.). Escola e leitura: velha crise; novas alternativas. São Paulo: Global, 2009.

PELLEGRINI, Tânia et alii. Literatura, cinema e televisão. São Paulo: Instituto Itaú Cultural, 2003.

ROJO, Roxane Helena R.; MOURA, Eduardo (Orgs.). Multiletramentos na escola. São Paulo: Parábola Editorial, 2012.

Hipermodernidade, multiletramentos e gêneros discursivos. São Paulo: Parábola Editorial, 2015.

SOARES, Magda. "A escolarização da literatura infantil e juvenil". In: EVANGELISTA, Aracy Alves M.; BRANDÃO, Heliana M. B.; MACHADO, Maria Z. V. (Orgs). A escolarização da leitura literária. O jogo do livro infantil e juvenil. Belo Horizonte: Autêntica, 1999.

SILVA, Solimar. Práticas de leitura: 150 ideias para despertar o interesse dos alunos. Rio de Janeiro: Vozes, 2018.

THIOLLENT, Michel. Metodologia de Pesquisa-ação. $18^{a}$ ed. São Paulo: Cortez, 2011. 


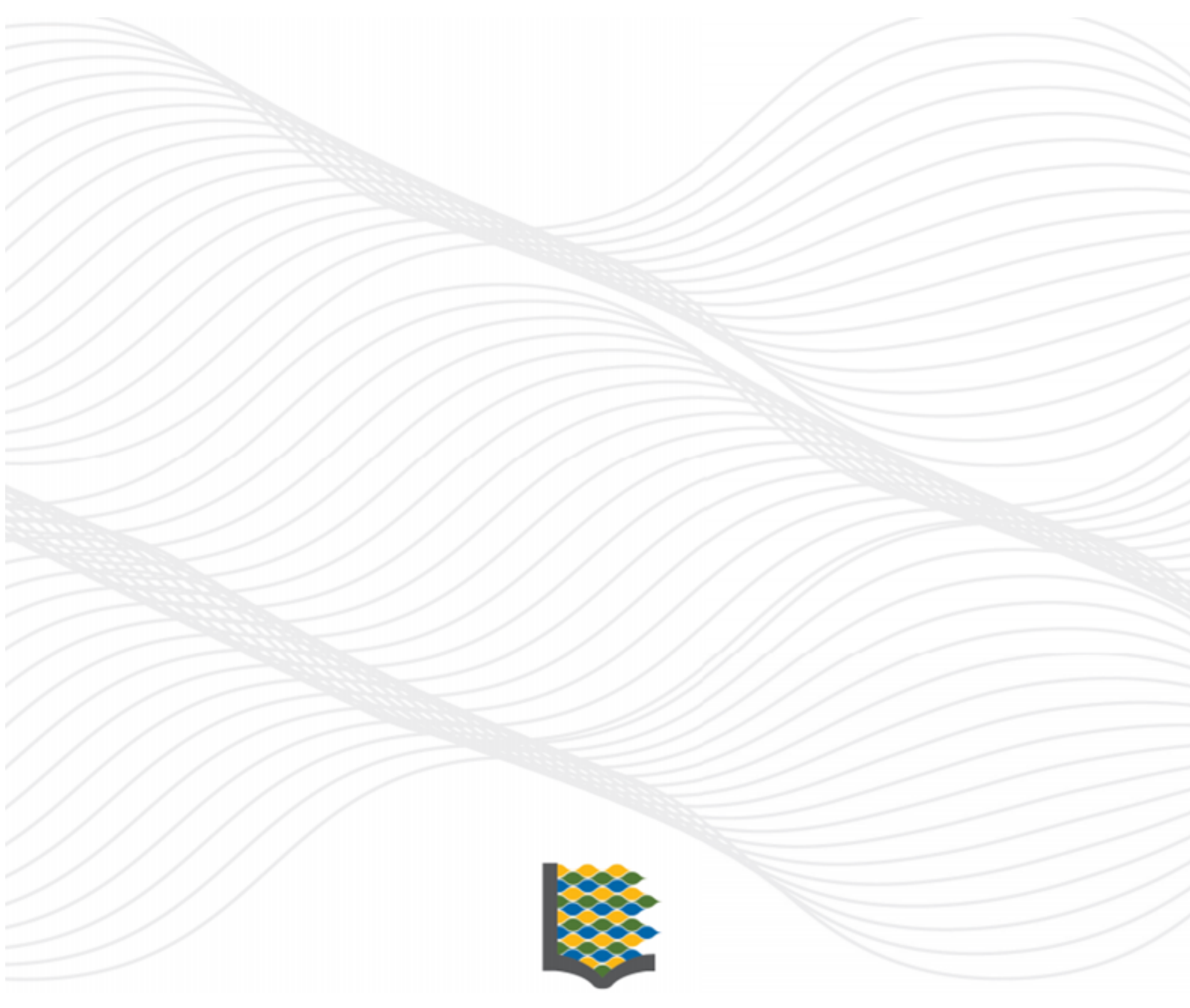

